\title{
Dampak Kebijakan MBKM Pada Kesiapan Sumber Daya Manusia dan Fasilitas Fakultas Hukum Usahid Jakarta
}

\author{
Yuherman*, Wahyu Nugroho**, Dessy Sunarsi*** \\ (**Penulis Korespondensi) \\ Fakultas Hukum, Universitas Sahid Jakarta*******
}

dikirim: 28 Desember 2021 direvisi:30 Desember 2021 diterima: 31 Desember 2021

\begin{abstract}
Abstrak:
Kebijakan Merdeka Belajar Kampus Merdeka (MBKM) akan berdampak pada Fakultas Hukum Usahid Jakarta, khususnya bagi dosen dan tenaga kependidikan, beserta kesiapan dan fasilitas pelaksanaan program MBKM pada Fakultas Hukum Usahid. Tujuan penelitian ini adalah pertama, untuk mengetahui dan menganalisis kesiapan pelaksanaan kebijakan MBKM dalam pengelolaan SDM pada Fakultas Hukum Usahid; dan kedua, untuk memperkuat adanya fasilitas pendukung pelaksanaan MBKM pada Fakultas Hukum Usahid. Dalam penelitian ini, digunakan dua metode, yakni pertama, penelitian kepustakaan; dan kedua, penelitian lapangan, yakni metode dengan melakukan survei kepada para mahasiswa Fakultas Hukum Usahid melalui sosialisasi dan FGD terkait kebijakan MBKM pada tingkat Fakultas Hukum Usahid. Hasil penelitian ini menunjukkan bahwa: pertama, Fakultas Hukum Usahid telah mempersiapkan terkait pelaksanaan kebijakan MBKM dengan berbagai peluang yang ada. Peluang tersebut berkaitan erat dengan kesiapan SDM, baik dosen pendamping/fasilitator guna merespon pilihan mahasiswa atas program MBKM, latar belakang dosen sekaligus praktisi, maupun tenaga kependidikan sebagai supporting administration system; kedua, Fakultas Hukum Usahid telah mempersiapkan berbagai fasilitas guna mempersiapkan mahasiswa dalam menetapkan pilihan program MBKM, diantaranya peradilan semu, LKBH dan lain sebagainya. Selain penguatan kelembagaan secara internal, juga penguatan eksternal melalui berbagai kerjasama beserta hasilnya dengan sejumlah institusi/lembaga negara di bidang hukum sebagai mitra.
\end{abstract}

Kata Kunci : MBKM, Fakultas Hukum Usahid, Kebijakan, Dosen, Mahasiswa.

\begin{abstract}
:
The Independent Learning Campus ((abbreviation in Indonesian: MBKM) policy will have an impact on the Faculty of Law Usahid Jakarta, especially for lecturers and education staff, as well as the readiness and facilities for implementing the MBKM program at the Faculty of Law Usahid. The purposes of this study are first, to determine and analyze the readiness of implementing MBKM policies in human resources management at the Faculty of Law Usahid; and second, to strengthen the existence of supporting facilities for the implementation of MBKM at the Faculty of Law Usahid. In this study, two methods were used, namely first, library research; and second, field research, namely the method by conducting a survey to law school student through socialization, and FGD related to MBKM policies at the Faculty of Law Usahid level. The results of this study indicate that: first, the Faculty of Law Usahid has prepared related to the implementation of the MBKM policy with various opportunities. These opportunities are closely related to the readiness of human resources, both assistant lecturers/facilitators to respond to student choices for the MBKM program, lecturers' and practitioners' backgrounds, as well as education staff as a supporting administration system; second, the Faculty of Law Usahid has prepared various facilities to prepare students in determining the choice of the MBKM program, including moot court, $L K B H$ and so on. In addition to internal institutional strengthening, external
\end{abstract}


strengthening is also carried out through various collaborations and their results with a number of state institutions/institutions in the field of law as partners.

Keywords : MBKM, Faculty of Law Usahid, Policy, Lecturers, Students.

\section{PENDAHULUAN}

Kebijakan Merdeka Belajar-Kampus Merdeka (MBKM) bersifat mandatory dari Kemenristek Dikti Republik Indonesia, akan tetapi menjadi opsi atau hak bagi mahasiswa. Kebijakan MBKM merupakan peluang dan tantangan untuk mewujudkan mahasiswa menjadi sarjana yang terampil dan berwawasan. Oleh sebab itu tantangan dan peluang ini harus dimaknai sebagai peluang dan tantangan bagi mahasiswa, perguruan tertinggi, termasuk Fakultas Hukum Universitas Sahid Jakarta, calon Mitra, baik swasta, institusi pemerintah maupun organisasi nirlaba.

Program MBKM harus pula disikapi sebagai media untuk merespon keniscayaan dalam menghadapai dinamika masyarakat dan perkembangan ilmu dan teknologi yang demikian cepatnya. Pada bagian ini, pemahaman terhadap teori dan praktik hukum harus berjalan mengikuti dinamika tersebut. Dalam hubungannya dengan dunia pendidikan, in casu Fakultas Hukum, harus menyikapi hal tersebut dalam mempersiapkan sarjana hukum yang siap dan terampil dalam menghadapi perkembangan sesuai dengan minat dan cita-citanya sebagai seorang sarjana hukum, yang terbuka untuk memilih peminatan keahlian di bidang hukum tertentu. Program MBKM terwujud ke dalam delapan contoh bentuk kegiatan pembelajaran, yaitu: (1) pertukaran pelajar, (2) magang/praktik kerja, (3) asistensi mengajar di satuan pendidikan, (4) penelitian/riset, (5) proyek kemanusiaan, (6) kegiatan wirausaha, (7) studi/proyek independen, dan (8) membangun desa/kuliah kerja nyata tematik.

Perkembangan hukum dan masyarakat ternyata juga melahirkan profesi hukum baru atau pekerjaan tertentu yang menuntut penguasaan hukum tertentu guna mendukung pilihan karir, usaha, atau profesi lainnya. Profesi hukum adalah suatu profesi yang berkenaan dengan bidang hukum. Profesi hukum berusaha untuk mewujudkan dan memelihara ketertiban yang berkeadilan di dalam kehidupan masyarakat. Profesi hukum mempunyai nilai moral yaitu: Kejujuran, otentik, bertanggung jawab, kemandirian moral, keberanian moral. Profesi hukum berusaha untuk mewujudkan dan memelihara ketertiban yang berkeadilan di dalam kehidupan masyarakat (Sinaga, 2020). Untuk itu pilihan Mata Kuliah dan lingkungan praktik hukum harus disinergikan dengan kebutuhan dan 
Morality: Jurnal Ilmu Hukum

keinginan tersebut, termasuk pilihan lembaga sebagai tempat praktik guna menguji penerapan keilmuan dan menambah wawasan mahasiswa sebagai calon sarjana hukum, yang mampu merespon segala perubahan di masyarakat.

Oleh sebab itu, mahasiswa dituntut untuk mengembangkan diri sejak dini yang berorientasi pada eksplorasi kemampuan, minat dan cita-citanya di bidang hukum. Di lain pihak Perguruan Tinggi sudah seharusnya pula merespon tuntutan perkembangan yang demikian, diantaranya dengan memaksimalkan dan mengefektifkan pelaksanaan MBKM. Untuk itu diperlukan metode, penyiapan fasilitas dan Sumber Daya Manusia pada perguruan tinggi, termasuk Fakultas Hukum Universitas Sahid Jakarta, baik dosen dengan pemenuhan standar kualifikasi berdasarkan peraturan perundang-undangan, maupun tenaga kependidikan sebagai supporting system yang mendukung secara administrasi dalam rangka melaksanakan kebijakan MBKM. Penulis telah mengidentifikasi beberapa artikel penelitian sebelumnya terkait kebijakan MBKM dari berbagai sudut pandang dan karakteristik setiap perguruan tinggi.

Berdasarkan hasil penelitian terkait kebijakan MBKM yang dilakukan oleh Nora Susilawati dalam perspektif
Desember 2021, Volume 7 Nomor 2

humanisme, bahwa kualitas belajar dan kebermaknaan belajar dapat dicapai dengan menerapkan prinsip belajar humanistik yaitu, belajar bagaimana belajar (learning how to learn), pembelajaran mandiri, memotivasi diri, dan pendidikan afektif. Dengan demikian, tujuan pendidikan MBKM yang diharapkan untuk mengembangkan hard skills dan soft skills, menyiapkan mahasiswa lebih siap dan relevan dengan kebutuhan perkembangan zaman, menyiapkan lulusan sebagai pemimpin masa depan bangsa yang unggul dan berkepribadian dapat dicapai secara optimal. MBKM memadukan kapabilitas dan potensi mahasiswa dan perguruan tinggi untuk mandiri memilih dan mengatur kegiatan pembelajaran MBKM. Kebijakan kampus merdeka menginginkan perguruan tinggi di Indonesia diberi ruang yang cukup untuk beradaptasi mengikuti perkembangan zaman. Prinsip terpenting yang dikandung dalam kampus merdeka adalah kemerdekaan akademik (academic freedom). Konsep ini umumnya digunakan dalam dunia pendidikan di perguruan tinggi (Nora Susilawati, 2021).

Penelitian lainnya dilakukan oleh Sudaryanto, Wahyu Widayati, dan Risza Amalia terkait penelitian MBKM yang diaplikasikan pada Prodi Pendidikan 
Morality: Jurnal Ilmu Hukum

Bahasa dan Sastra Indonesia Fakultas

Keguruan dan Ilmu Pendidikan,

Universitas Ahmad Dahlan, Yogyakarta, bahwa diantara kedelapan program MBKM, empat program sudah dilaksanakan pada Program Studi Pendidikan Bahasa dan Sastra Indonesia, Fakultas Keguruan dan Ilmu Pendidikan, Universitas Ahmad Dahlan, Yogyakarta. Empat kegiatan yang dimaksud ialah magang penyuntingan dalam mata kuliah Penyuntingan (bobot 2 SKS; semester 7), asistensi mengajar di satuan pendidikan dalam mata kuliah Pengenalan Lapangan Persekolahan 2 (bobot 3 SKS; semester antara 6 dan 7), penelitian/riset dalam mata kuliah Penelitian Bahasa, Penelitian Sastra, dan Penelitian Pendidikan (bobot 2 SKS; semester 6), dan membangun desa/kuliah kerja nyata tematik dalam mata kuliah KKN (bobot 4 SKS; semester 7 dan semester antara 7 dan 8. Pada program studi tersebut, terdapat mata kuliah Penyuntingan yang mendorong mahasiswa untuk magang penyuntingan di penerbit Samudra Biru dan K-Media, mata kuliah KKN yang mendorong mahasiswa aktif membangun desa, dan mata kuliah Penelitian Bahasa, Penelitian Sastra, dan Penelitian Pendidikan yang mendorong mahasiswa melakukan penelitian (Sudaryanto, Wahyu Widayati, dan Risza Amalia, 2020).
Desember 2021, Volume 7 Nomor 2

Penelitian selanjutnya dilakukan oleh Nurhayani Siregar, Rafidatun Sahirah, \& Arsikal Amsal Harahap, terkait konsep kampus merdeka belajar di era revolusi industri 4.0. Hasil penelitiannya terungkap bahwa bahwa konsep belajar tiga semester di luar prodi ini hadir dikarenakan beberapa hal diantaranya bahwa dari segi menemukan jati diri mahasiswa, dimana masih terdapat mahasiswa yang merasa salah jurusan atau merasa tidak cocok dengan prodinya. maka dengan konsep belajar tiga semester di luar prodi, ia akan memiliki pengalaman belajar. Selain itu, dinyatakan bahwa konsep kampus merdeka pada point belajar tiga semester di luar prodi merupakan upaya untuk melatih mahasiswa dengan berbagai pengalaman belajar sehingga terbiasa dalam menghadapi tantangan di dunia nyata. Sebagaimana yang dikemukakan Mendikbud, kurang lebih bahwa jika mahasiswa hanya diajarkan di kolam renang dengan satu gaya berenang, lalu bagaimana ia menghadapi kondisi laut yang bervariatif. serta beliau mengemukakan kurang lebih bahwa, hampir tidak ada profesi sekarang yang hanya menggunakan satu rumpun ilmu. namun membutuhkan kombinasi dari beberapa disiplin ilmu. Dalam menghadapi era revolusi industri 4.0, konsep kampus merdeka belajar pada point hak belajar tiga 
Morality: Jurnal Ilmu Hukum

semester di luar prodi, memiliki kelebihan diantaranya menambah wawasan ilmu pengetahuan dan pengalaman belajar bagi mahasiswa, karena dengan belajar tiga semester di luar prodi, memberikanpengalaman dan ilmu yang luas, sebagaimana yang dikemukakan oleh Mendikbud, kurang lebih bahwa yang terpenting dalam periode pendidikan tinggi adalah menemukan kehausan untuk terus belajar, jatuh cinta dengan proses pembelajaran (Nurhayani Siregar, Rafidatun Sahirah, \& Arsikal Amsal Harahap, 2020).

Penelitian berikutnya dilakukan oleh Nensi Nofa Nofia terkait analisis tantangan implementasi kebijakan MBKM pada perguruan tinggi islam negeri di Indonesia, terungkap bahwa terdapat beberapa kendala dalam pelaksanaan kebijakan MBKM, diantaranya adalah biaya yang cukup besar, kecuali suatu institusi mampu melakukannya dan memiliki dana yang cukup besar maka pasti hasilnya memuaskan. Ada beberapa kampus yang sudah menerapkan atau mengimplementasikannya, tidak semua kampus mampu menerapkannya. Jadi banyak sekali hal-hal yang harus dipersiapkan dalam mengimplementasikan merdeka belajar kampus merdeka ini. Tantangannya adalah perguruan tinggi kecil dengan keterbatasan sumber daya
Desember 2021, Volume 7 Nomor 2

manusia, sarana prasarana, dan terutama PTN dengan letak geografis terpencil tentu memiliki rintangan besar untuk berkolaborasi dengan instansi besar dan PTN Unggulan untuk mewujudkan kolaborasi yang produktif dan bermakna bagi pengembangan keilmuan dan pengalaman mahasiswa. Tanpa adanya mekanisme yang jelas serta adanya visi bersama antara Kemendikbud dengan Kementerian lainnya, kebijakan ini dirasa hanya bagus secara aturan tetapi memunculkan masalah pada penerapan/implementasiya (Nensi Nofa Nofia, 2020).

Berkenaan dengan kebijakan MBKM ini, maka Fakultas Hukum USAHID dengan program studi ilmu hukumnya, yang terdiri dari peminatan Hukum Bisnis dan peminatan Hukum Acara, tentu harus mererspon dan mempersiapkan MBKM dalam rangka mendorong mahasiswa fakultas hukum untuk menguasai dan memiliki ketrampilan di bidang ilmu hukum dan praktik sesuai dengan bidang profesi atau kajian keilmuan hukum yang diminatinya dalam lingkup hukum bisnis dan hukum acara tersebut. Fakultas Hukum USAHID optimis untuk pencapaian tersebut atas pertimbangan dekat dan mudahnya informasi terhadap perkembangan hukum dan kelembagaannya, tenaga pengajar 
Morality: Jurnal Ilmu Hukum

yang adalah juga akademisi dan praktisi, serta kelembagaan internal Fakultas dan Universitas, tentunya dengan penataan dan memaksimalkan fungsinya untuk mengantarkan mahasiswa fakultas hukum menekuni profesi hukum dan sesuai dengan standar nasional pendidikan tinggi.

Kesiapan pengelolaan SDM dan fasilitas prasarana terkait pelayanan kebijakan MBKM pada Fakultas Hukum Usahid Jakarta menjadi ruang lingkup dan batasan dalam penelitian ini dalam rangka mempersiapkan mahasiswa fakultas hukum menghadapi berbagai perubahan sosial-budaya, hukum, dunia kerja dan pesatnya teknologi yang berimplikasi pada profesi hukum. Fakultas Hukum Usahid Jakarta didesain dalam rangka melaksanakan proses pembelajaran yang kreatif dan inovatif, sehingga para mahasiswa mampu menghasilkan capaian pembelajaran sikap, pengetahuan, dan ketrampilan yang optimal.

Berdasarkan latar belakang tersebut dan hasil penelusuran beberapa artikel penelitian terkait sebelumnya, belum pernah ada penelitian yang membahas terkait kesiapan SDM dan fasilitas pada Fakultas Hukum dalam kebijakan MBKM, sementara beberapa penelitian tersebut memiliki sudut pandang \& karakteristik setiap fakultas dan universitas, serta kondisi dan kendala teknis yang beragam
Desember 2021, Volume 7 Nomor 2

dalam pelaksanaan MBKM di setiap institusi perguruan tinggi. Fakultas Hukum Usahid Jakarta akan melakukan pendalaman lebih lanjut dalam kaitannya dengan kebijakan program Merdeka Belajar-Kampus Merdeka dihubungkan dengan kesiapan pelaksanaan regulasi terkait, utamanya berkenaan dengan kesiapan dan pengelolaan SDM, baik dosen dan tenaga kependidikan, maupun berbagai fasilitas pendukungnya. Kebijakan MBKM pada Fakultas Hukum Usahid harus tetap menjaga relevansinya dengan capaian pembelajaran dan lulusan pada peminatan hukum bisnis dan hukum acara pada Prodi Ilmu Hukum Fakultas Hukum Usahid Jakarta, sehingga mampu menjawab tantangan perkembangan masyarakat, kemajuan teknologi, dan tuntutan dunia profesi hukum.

Dalam artikel hasil penelitian ini, rumusan masalahnya adalah pertama, bagaimana kesiapan dan pengelolaan SDM pada Fakultas Hukum Usahid Jakarta dalam penerapan kebijakan MBKM? dan kedua, bagaimana fasilitas pendukung untuk pelaksanaan kebijakan MBKM bagi Fakultas Hukum Usahid Jakarta?

Selanjutnya berkaitan dengan metode penelitian yang digunakan dalam penelitian ini adalah menggunakan dua metode, yakni: pertama, metode dengan melakukan survei kepada para mahasiswa 
Morality: Jurnal Ilmu Hukum

Fakultas Hukum Usahid Jakarta melalui sosialisasi program MBKM; dan kedua, metode Focus Group Discussion (FGD) kepada para dosen di lingkungan Fakultas Hukum Usahid Jakarta terkait kebijakan MBKM pada tingkat Fakultas Hukum Usahid Jakarta. Teknik pengumpulan data menggunakan kepustakaan, studi peraturan perundang-undangan, dan Focus Group Discussion (FGD). Analisis data menggunakan analisis deskriptif kualitatif, yakni melakukan analisis secara kualitatif atas hasil pembahasan yang bersumber dari penelitian kepustakaan dan penelitian lapangan.

Dalam melakukan pembahasan ini dengan berpijak pada permasalahan penelitian, akan dianalisis menggunakan teori kebijakan publik. Menurut Thomas R. Dye sebagaimana dikutip oleh Amri Marzali, bahwa kebijakan negara didefinisikan sebagai is whatever governmenet choose to do or not to do, dan dikatakan pilihan bagi pemerintah untuk melakukan sesuatu, harus ada tujuan secara objektif dan kebijakan negara harus mencakup berbagai tindakan pemerintah. Hal ini bukanlah hanya sebagai pernyataan keinginan pemerintah atau pejabat pemerintah, melainkan sesuatu yang tidak dilakukan oleh pemerintah akan mempunyai pengaruh yang sama besarnya
Desember 2021, Volume 7 Nomor 2

dengan sesuatu yang dilakukan oleh pemerintah (Marzali, 2012).

Selain itu, teori kebijakan publik, dalam konteks kebijakan yang ditetapkan oleh Menteri Pendidikan dan Kebudayaan melalui kebijakan merdeka belajar kampus merdeka, tentunya terdapat 5 (lima) unsur terpenting yang berkaitan dengan kebijakan publik. Unsur pertama, adalah tujuan atau kegiatan yang berorientasi tujuan haruslah menjadi perhatian utama perilaku acak atau peristiwa yang tiba-tiba terjadi; unsur kedua, kebijakan merupakan pola model tindakan pejabat pemerintah mengenai keputusan-keputusan diskresinya secara terpisah; unsur ketiga, kebijakan harus mencakup apa yang nyata pemerintah perbuat, atau apa yang mereka katakan akan dikerjakan; unsur keempat, bentuk kebijakan publik dalam bentuknya yang positif didasarkan pada ketentuan hukum dan kewenangan; dan unsur kelima, bahwa tujuan kebijakan publik adalah dapat dicapainya kesejahteraan masyarakat melalui produk kebijakan yang dibuat oleh pemerintah (Tahir, 2011).

Teori kebijakan digunakan untuk menganalisis kesiapan dalam pengelolaan sumber daya manusia pada Fakultas Hukum Usahid Jakarta atas pelaksanaan program MBKM. Analisis kebijakan publik melalui program MBKM untuk diketahui kesiapan-kesiapan SDM dan 
Morality: Jurnal Ilmu Hukum

fasilitas sebagai infrastruktur pendukung program MBKM. Apa yang menjadi kebutuhan SDM, fasilitas, dan berbagai variabel atau faktor yang mempengaruhi pelaksanaan program MBKM ke depan di Fakultas Hukum Usahid, sehingga kebijakan publik terkait MBKM akan mampu selaras dengan tujuan-tujuan yang dikehendaki oleh pembuat kebijakan di bidang Pendidikan tinggi melalui MBKM.

\section{PEMBAHASAN}

\section{A. Pengertian Belajar \& Konsep Dasar} Merdeka Belajar-Kampus Merdeka (MBKM)

Pengertian belajar menurut Harold Spears adalah: learning is to observe, to read, to imitate, to try something themselves, to listen to follow direction (belajar adalah mengamati, membaca, meniru, mencoba sesuatu pada dirinya sendiri, mendengar dan mengikuti aturan). Sementara Singer (1968) mendefinisikan belajar sebagai perubahan yang relatif tetap, disebabkan praktik atau pengalaman yang sampai pada saat situasi tertentu (Yuberti, 2014).

Kemerdekaan belajar yang dikemukakan oleh Menristek Dikti, Bapak Nadiem Anwar Makarim adalah:

"Memberikan kebebasan dan otonomi kepada lembaga Pendidikan, dan merdeka dari birokratisasi, dosen dibebaskan dari birokrasi yang berbelit, serta mahasiswa diberikan kebebasan untuk memilih bidang
Desember 2021, Volume 7 Nomor 2

yang mereka sukai" (Buku Panduan Merdeka Belajar-Kampus Merdeka Direktorat Jenderal Pendidikan Tinggi, 2020).

Konsep Merdeka Belajar Kampus Merdeka sebagai bagian dari kebijakan/program Menristek Dikti, salah satunya adalah hak belajar tiga semester di luar program studi yang diluncurkan sejak tahun 2020 oleh Menteri Pendidikan dan Kebudayaan (Harian Kompas, 2020). Program tersebut merujuk kepada dasar hukum terkait pendidikan tinggi dalam rangka peningkatan kualitas dalam proses pembelajaran dan lulusan pendidikan tinggi. Tujuan program MBKM adalah mendorong mahasiswa untuk mempunyai kompetensi dan menguasai berbagai keilmuan yang dipersiapkan untuk memasuki dunia kerja. Kampus Merdeka memberikan peluang kepada mahasiswa untuk memilih mata kuliah tertentu yang akan mereka pilih sesuai dengan peminatannya.

B. Kebijakan dan regulasi terkait Merdeka Belajar Kampus Merdeka

Kebijakan Merdeka Belajar Kampus Merdeka merupakan kebijakan yang ditetapkan oleh pusat melalui Kemenristek Dikti. Namun, apabila ditelusuri berbagai dasar hukum yang ada, tidak ditemukan istilah merdeka belajar tercantum dalam norma peraturan perundang-undangan. Pernyataan Merdeka Belajar Kampus 
Morality: Jurnal Ilmu Hukum

Merdeka sebagai perwujudan dari spirit/nilai (value) yang kemudian diwujudkan dalam sebuah program yang konkrit dan secara implisit tercantum di dalam ketentuan Pasal 18 Permendikbud Nomor 3 Tahun 2020 tentang Standar Nasional Pendidikan Tinggi. Pasal 18 menyatakan bahwa:

(1) Pemenuhan masa dan beban belajar bagi mahasiswa program sarjana atau program sarjana terapan sebagaimana dimaksud dalam Pasal 17 ayat (1) huruf $\mathrm{d}$ dapat dilaksanakan dengan cara:

a. Mengikuti seluruh proses Pembelajaran dalam Program Studi pada Perguruan Tinggi sesuai masa dan beban belajar; atau

b. Mengikuti proses Pembelajaran di dalam Program Studi untuk memenuhi sebagian masa dan beban belajar dan sisanya mengikuti proses Pembelajaran di luar Program Studi sebagaimana dimaksud dalam Pasal 15 ayat (1) dan ayat (2).

(2) Perguruan Tinggi wajib memfasilitasi pelaksanaan pemenuhan masa dan beban belajar dalam proses Pembelajaran sebagaimana dimaksud pada ayat (1).

(3) Fasilitasi oleh Perguruan Tinggi untuk pemenuhan masa dan beban belajar
Desember 2021, Volume 7 Nomor 2

dalam proses Pembelajaran sebagaimana dimaksud pada ayat (1) huruf $\mathrm{b}$ dengan cara sebagai berikut:

a. Paling sedikit 4 (empat) semester dan paling lama 11 (sebelas) semester merupakan Pembelajaran di dalam Program Studi;

b. 1 (satu) semester atau setara dengan 20 (dua puluh) sks merupakan Pembelajaran di luar Program Studi pada Perguruan Tinggi yang sama; dan;

c. paling lama 2 (dua) semester atau setara dengan 40 (empat puluh) sks merupakan:

1. Pembelajaran pada Program Studi yang sama di Perguruan Tinggi yang berbeda;

2. Pembelajaran pada Program Studi yang berbeda di Perguruan Tinggi yang berbeda; dan/atau

3. Pembelajaran di luar Perguruan Tinggi.

Ketentuan dalam Permendikbud No. 3 Tahun 2020 tentang Standar Nasional Pendidikan Tinggi merupakan peraturan pelaksanaan dari ketentuan Pasal 52 ayat (3) Undang-Undang Nomor 12 Tahun 2012 tentang Pendidikan Tinggi. Selain menyandarkan pada regulasi tersebut juga memiliki keterkaitan dengan berbagai regulasi di bidang Pendidikan tinggi, 
diantaranya adalah pertama, Undang-

Undang Nomor 20 Tahun 2003 tentang

Sistem Pendidikan Nasional; kedua, Peraturan Pemerintah Nomor 04 Tahun 2014 tentang Penyelenggaraan Pendidikan Tinggi dan Pengelolaan Perguruan Tinggi; ketiga, Peraturan Presiden Nomor 8 Tahun 2012, tentang Kerangka Kualifikasi Nasional Indonesia (KKNI); keempat, Keputusan Menteri Pendidikan dan Kebudayaan NOMOR 754/ P/2020 tentang Indikator Kinerja Utama Perguruan Tinggi Negeri dan Lembaga Layanan Pendidikan Tinggi di Lingkungan Kementerian Pendidikan dan Kebudayaan Tahun 2020; kelima, Keputusan Rektor Universitas Sahid Jakarta Nomor 130/USJ-01/A50/2020 tentang Panduan Akademik Merdeka Belajar-Kampus Merdeka Universitas Sahid Jakarta; dan keenam, Panduan Penyusunan Kurikulum Pendidikan Tinggi, Di Era Industri 4.0 Untuk Mendukung Merdeka BelajarKampus Merdeka (Kemenristekdikti, 2020).

\section{Kesiapan Pengelolaan SDM terkait} Kebijakan MBKM pada Fakultas Hukum Usahid Jakarta

1. Umpan balik mahasiswa hukum terhadap kebijakan MBKM pada Fakultas Hukum Usahid Jakarta

Kebijakan MKBM memiliki peluang dan tantangan bagi para mahasiswa, khususnya Fakultas Hukum Usahid Jakarta. Mahasiswa hukum akan diperhadapkan oleh suatu kondisi atas permasalahan atau fenomena sosialkemasyarakatan secara riil, khususnya pada aspek hukum dan penegakan hukum, sementara berbagai mata kuliah yang diambil dari proses pembelajaran, harus menyeimbangkan dalam tataran teoritis maupun praktik hukum di masyarakat, memecahkan permasalahan hukum melalui layanan konsultasi \& bantuan hukum, hingga beracara di pengadilan dan institusi penegakan hukum yang lain. Selain itu, mahasiswa hukum dibekali mata kuliah Etika Profesi Hukum, agar etika menjadi pegangan dalam proses penegakan hukum. Dalam konteks penegakan hukum, etika dapat dimaknai sebagai seperangkat prinsip moral yang membedakan apa yang benar dan apa yang salah, apa yang pantas dan tidak pantas untuk dilakukan oleh seorang penegak hukum. Etika ini harus menjadi pegangan, bagi aparat penegak hukum, baik manakala ia menjalankan tugas dan fungsinya sebagai penegak hukum, maupun dalam aktivitas seharihari sebagai warga masyarakat (Miswardi, dkk., 2021).

Permasalahan yang dihadapi oleh mahasiswa Fakultas Hukum Usahid Jakarta saat ini adalah belum mengetahui sepenuhnya program MBKM. Mereka 
Morality: Jurnal Ilmu Hukum

hanya mendengar berbagai lontaran terkait merdeka belajar yang dikemukakan oleh pemerintah dan para pengajar di beberapa webinar, namun tidak mengetahui secara substansi dan detail terkait program MBKM tersebut.

Berdasarkan hasil dari sosialisasi MBKM (Merdeka Belajar-Kampus Merdeka) yang diselenggarakan oleh Fakultas Hukum Universitas Sahid Jakarta pada hari Rabu, 15 Desember 2021, melalui virtual zoom (Sosialisasi MBKM, 2021). Pesertanya adalah para mahasiswa Fakultas Hukum Usahid Jakarta dengan narasumber dari pihak Tim Penyusun Pedoman Merdeka Belajar-Kampus Merdeka pada Universitas Sahid Jakarta, yang diwakili oleh Bapak Tanjung Prasetyo, memberikan paparan terkait panduan program MBKM pada tingkat universitas dan fakultas hukum. Sebagian besar mereka belum memahami detail tentang program Merdeka Belajar-Kampus Merdeka. Hal tersebut diantaranya dikarenakan secara institusi universitas, belum melaksanakan program MBKM untuk diterapkan pada semua fakultas.

Sungguhpun demikian, sejatinya Fakultas Hukum Usahid Jakarta telah mendorong dan memfasilitasi mahasiswa Fakultas Hukum Usahid Jakarta melalui kegiatan-kegiatan yang pada dasarnya merupakan nilai-nilai yang dimaksudkan
Desember 2021, Volume 7 Nomor 2

dalam kebijakan MBKM. Kegiatan tersebut diantaranya adalah dengan memfasilitasi mahasiswa dalam program pemagangan, mengikutsertakan mahasiswa dalam penelitian dosen dan pengabdian kepada masyarakat. Akan tetapi kegiatan tersebut belum diformalkan atau belum terstruktur sesuai dengan mekanisme kebijakan MBKM untuk dapat terdaftar dan disetarakan beban studi (SKS) yang ada pada kurikulum Prodi Ilmu Hukum Fakultas Hukum Usahid Jakarta.

Dalam forum sosialisasi program MBKM kepada para mahasiswa fakultas hukum semua angkatan tersebut, mahasiswa mempertanyakan program MBKM apakah juga diperuntukkan bagi mahasiswa kelas karyawan/ekstensi, dengan mempertimbangkan hak mahasiswa. Informasi nara sumber sosialisasi MBKM, bahwa untuk saat ini, program MBKM ditujukan kepada mahasiswa regular, dan belum diperuntukkan bagi mahasiswa kelas ekstensi (karyawan). Namun, untuk ke depan, dapat dimungkinkan berkembang untuk diterapkan program MBKM kepada mahasiswa ekstensi (karyawan), karena juga menjadi hak mahasiswa untuk mengambil program MBKM. Benang merahnya adalah bahwa semangat berbagai regulasi atas program MBKM 
Morality: Jurnal Ilmu Hukum

merupakan hak mahasiswa yang harus difasilitasi.

Berkaitan dengan pelaksanaan magang, harus diselaraskan dengan prodi dan capaian pembelajaran, sehingga dampak kebijakan MBKM pada Fakultas Hukum Usahid berkorelasi juga dengan prodi. Misalnya berkaitan dengan mata kuliah Hukum Acara Mahkamah Konstitusi. Penulis yang juga berprofesi sebagai advokat, merupakan salah satu anggota organisasi Asosiasi Pengajar Hukum Tata Negara-Hukum Administrasi Negara (APTHN-HAN), mengampu salah satu mata kuliah Hukum Acara Mahkamah Konstitusi. Dalam beberapa perkara pengujian undang-undang dan penyelesaian hasil sengketa pemilihan umum kepala daerah, penulis berpraktik di Mahkamah Konstitusi menjadi kuasa hukum, dengan mewajibkan para mahasiswa untuk mengikuti jalannya persidangan di Mahkamah Konstitusi. Dalam proses pengajaran mata kuliah Hukum Acara Mahkamah Konstitusi, capaian pembelajarannya adalah mahasiswa mampu memahami dan menguraikan beberapa tahapan dalam persidangan di Mahkamah Konstitusi atas pengujian undang-undang dan penyelesaian sengketa hasil pemilihan umum/pemilihan umum kepala daerah. Dalam kaitannya dengan pelaksanaan
Desember 2021, Volume 7 Nomor 2

program MBKM, pemagangan di Mahkamah Konstitusi, mengikuti seluruh rangkaian persidangan, dan penugasan mata kuliah Hukum Acara Mahkamah Konstitusi menjadi bagian dari capaian pembelajaran dengan mengkolaborasikan antara proses perkuliahan dengan pemagangan dan mengikuti jalannya persidangan di Mahkamah Konstitusi.

Selanjutnya, juga disampaikan bahwa apabila mahasiswa gagal dalam seleksi pengajuan proposal MBKM, maka mahasiswa dapat mengikuti proses seleksi program MBKM berikutnya. Hal ini merupakan hak dari mahasiswa untuk mengikuti dan lolos seleksi, sehingga dapat diberikan kesempatan kembali untuk mengikuti proses seleksi atas program MBKM tersebut. Hal ini menjadi pertimbangan mengingat pencapaian kuota dan mitra fakultas hukum yang cukup banyak, sehingga dibuka peluang yang banyak. Memperhatikan kondisi tersebut, maka kebijakan untuk membuka dan membangun jejaring, mitra dengan institusi lain terkait bidang hukum harus dimaksimalkan.

\section{Kualifikasi SDM dan Kesiapan Fakultas Hukum Usahid Jakarta dalam Program MBKM}

Dalam rangka melaksanakan program MBKM pada Fakultas Hukum Usahid Jakarta, maka diperlukan kesiapan 
Morality: Jurnal Ilmu Hukum

SDM yang berkualitas dan memiliki kemampuan mengakselerasikan antara tataran teoritis dengan praktis, khususnya di bidang hukum. Pada umumnya, SDM yang merupakan tenaga pengajar pada Fakultas Hukum Usahid Jakarta merupakan praktisi hukum atau mempunyai latar belakang profesi dan karir, sebagai advokat/lawyer, kurator, mediator, penyidik, notaris dan hakim. Hal tersebut sebagai bagian dari kekuatan SDM dan peluang yang dimanfaatkan Fakultas Hukum untuk mengoptimalkan SDM yang memenuhi kualifikasi dan standar dosen pengampu mata kuliah pada Fakultas Hukum Usahid Jakarta.

Untuk mengelaborasi dan memperkuat kapasitas SDM, Fakultas Hukum Usahid telah menyelenggarakan Focus Group Discussion (FGD) secara internal yang pesertanya adalah para dosen di lingkungan Fakultas Hukum Usahid di hotel bidakara pada tanggal 17 Desember 2021 (FGD FH Usahid, 2021). Hasilnya adalah penguatan sinergi antar institusi Perguruan Tinggi dan lembaga di bidang penegakan hukum, penguatan fasilitas Peradilan Semu, dan memperkuat kurikulum untuk mempersiapkan pilihan praktik magang mahasiswa dalam program MBKM.

Meskipun demikian, persoalan teknis pelaksanaan MBKM masih perlu
Desember 2021, Volume 7 Nomor 2

ditegaskan oleh universitas berikut sosialisasinya kepada seluruh SDM, selain menyangkut kebijakan universitas dalam persoalan penyediaan SDM dan pendanaan terkait, juga berkenaan dengan perjanjian kerja sama dengan mitra yang akan menjadi target program MBKM, bahwa berdasarkan Surat Keputusan Rektor Usahid, perjanjian kerja sama dilakukan di tingkat universitas.

Kekuatan SDM yang dimiliki oleh fakultas hukum akan semakin memperkuat kerja sama antar lembaga/institusi di bidang hukum dalam program MBKM, yang sekaligus juga untuk menyinergikan antara dunia Pendidikan Tinggi hukum dengan kebutuhan dan praktik hukum di masyarakat. Kemampuan untuk memanfaatkan peluang ini menjadi faktor yang berpengaruh terhadap kualitas lulusan Sarjana Hukum, untuk siap memasuki dunia profesi hukum dan praktik hukum di masyarakat, merespon berbagai isu aktual yang berkembang di masyarakat untuk kemudian mampu menyelesaiakan permasalahan hukumnya secara intelektual dan berintegritas.

Penguatan kapasitas SDM pada Fakultas Hukum Usahid Jakarta sebagai unsur pendukung program MBKM dilakukan pula melalui pelatihan dan peningkatan produktivitas dalam penulisan artikel jurnal baik nasional ber-ISSN, 
Morality: Jurnal Ilmu Hukum

jurnal nasional terakreditasi dikti, dan jurnal internasional bereputasi. Selain itu, juga melalui pelatihan-pelatihan dan memperluas kegiatan pengabdian kepada masyarakat di bidang hukum, sosiohumaniora, dan isu-isu hukum, sosial, dan kebijakan publik. Kegiatan lainnya oleh para dosen dan institusi Fakultas Hukum Usahid dalam rangka penguatan kapasitas SDM adalah penelitian dosen yang melibatkan mahasiswa, sehingga dapat menjadi penelitian kolaboratif dan menganalisis isu-isu hukum di masyarakat, serta mengadakan berbagai webinar di bidang hukum dan kebijakan publik, guna menyikapi dan merespon terhadap permasalahan hukum dan kebijakan secara aktual dan kontekstual, baik secara nasional maupun di daerah, sesuai dengan karakter setiap mata kuliah yang diampu oleh dosen.

Untuk mendukung pelaksanaan program MBKM, kegiatan para dosen Fakultas Hukum Usahid Jakarta di luar kampus yang berkaitan dengan penelitian dan pengabdian masyarakat sesuai dengan bidang keilmuan dosen juga harus dimaksimalkan dengan melibatkan mahasiswa. Profesi-profesi seperti advokat, notaris, polisi, tenaga ahli pada lembaga negara, pengurus perusahaan atau corporate lawyer, mediator, konsultan HKI, Kurator, dan pengurus organisasi
Desember 2021, Volume 7 Nomor 2

profesi/keilmuan, serta pengurus organisasi di bidang isu-isu gender akan membuka peluang untuk memperbanyak pilihan dalam praktik MBKM bagi mahasiswa. Hal ini akan menjadi peluang sekaligus kekuatan yang dimiliki oleh SDM yang ada di Fakultas Hukum Usahid untuk menyelaraskan antara pembelajaran pada ruang-ruang kuliah dalam tataran teori dan praktik hukum pada berbagai profesi hukum, lembaga negara, dan perusahaan yang berkaitan dengan aspek hukum.

Tantangan ke depan dari program MBKM pada Fakultas Hukum Usahid Jakarta adalah disrupsi profesi hukum yang mengarahkan pada digitalisasi profesi hukum, misalnya profesi lawyer telah tergantikan oleh berbagai macam aplikasi jasa layanan konsultasi hukum yang tersedia secara elektronik, sehingga ada ancaman terjadi runtuhnya profesi lawyer di era digital dan menjadi pengacara cyber (Wahyu Nugroho, 2021).

Berbagai program MBKM memiliki dampak terhadap tuntutan kesiapan dosen sebagai fasilitator atau pendamping magang dan Tenaga Pendidikan sebagai pendukungnya, seperti pada program magang. Dalam program magang, selain mahasiswa harus memenuhi berbagai persyaratan yang telah ditentukan oleh Prodi, seperti syarat IPK dan keharusan 
Morality: Jurnal Ilmu Hukum

memiliki sertifikat pelatihan tertentu dari universitas dan fakultas, kesiapan SDM Dosen sebagai fasilitator atau pendamping juga merupakan hal yang harus dipetakan, utamanya terkait dengan ketersediaan waktu dan kebutuhan keahlian/bidang kekhususan keilmuan yang harus dimiliki untuk pendamping magang di bidang tertentu. Demikian pula dengan Tenaga Kependidikan yang harus mempersiapkan diri di bidang administrasi dan komunikasi yang bersifat teknis kepada para mahasiswa, terutama dalam pemannfaatan fasilitas Informasi dan Teknologi (IT).

Untuk saat ini, Prodi Ilmu Hukum Fakulas Hukum Usahid Jakarta baru pada tahapan persiapan perkuliahan lintas Prodi dan dalam proses penyiapan program magang dan program lainnya dalam rangka MBKM sesuai kebijakan universitas. Untuk program MBKM lainnya harus disiapkan lebih baik disesuaikan dengan peminatan pada Prodi Ilmu Hukum untuk menampung dan mendorong percepatan eksplorasi potensi dan minat mahasiswa melalui program MBKM.

Persiapan pelaksanaan kebijakan/program MBKM dengan berbagai peluang dan tantangan yang dihadapi akan berkaitan erat dengan kesiapan SDM, baik dosen Fakultas Hukum Usahid Jakarta yang harus terus
Desember 2021, Volume 7 Nomor 2

meningkatkan kapasitas dan kegiatan Tri Dharma pergurusan tingginya, maupun Tenaga Kependidikan sebagai supporting administration system, untuk memudahkan mahasiswa dalam mengambil program MBKM sesuai dengan bidang ilmu yang diminatinya, karena terkait dengan beragam profesi hukum dan munculnya berbagai macam profesi hukum baru. Selain itu, Fakultas Hukum Usahid sedang dalam proses persiapan dosen pendamping/fasilitator untuk merespon berbagai pilihan mahasiswa atas program MBKM, sementara di sisi lain dihadapkan pada tugas rutin dalam proses pembelajaran. Peningkatan kapasitas SDM dalam rangka pelaksanaan MBKM melalui berbagai pelatihan akademik dan aktivitas di luar kampus melalui kegiatan pengembangan penelitian dan pengabdian masyarakat sesuai dengan bidang keilmuan dosen.

Fakultas Hukum Usahid telah melakukan penguatan secara eksternal dalam kerangka membangun dan mengembangkan sejumlah kegiatan dengan Mitra melalui kerjasama dengan berbagai institusi/lembaga negara di bidang hukum dan penegakannya, seperti Kepolisian, Kejaksaan, Komisi Pemberantasan Korupsi (KPK), Komisi Yudisial (KY), Mahkamah Konstitusi (MK), Mahkamah Agung (MA) dan 
Morality: Jurnal Ilmu Hukum

berbagai pengadilan di Jakarta, baik Pengadilan Negeri, Pengadilan Agama, Pengadilan Militer maupun Pengadilan Tata Usaha Negara. Contoh hasil kerjasama dengan institusi Kepolisian melalui program system blended learning dalam perkuliahan S1 Ilmu Hukum pada Pendidikan Tinggi Kepolisian. Selanjutnya pada institusi KPK, Kerjasama FH Usahid dalam bentuk perekaman dalam persidangan tindak pidana korupsi di Pengadilan Tipikor Jakarta Pusat, yang penganggarannya dari KPK. FH Usahid sejak tahun 2008, merupakan kampus pertama kali yang mendapatkan penugasan melalui Kerjasama dengan KPK dalam bentuk perekaman persidangan tipikor yang dilakukan oleh para mahasiswa Fakultas Hukum Usahid Semester 5 (lima) dengan dosen pendamping. Beberapa hasil kerjasama lainnya antara FH Usahid dengan Komisi Yudisial adalah dalam bentuk penelitian penulisan buku yang diterbitkan oleh institusi KY, mitra bestari pada Jurnal Yudisial Komisi Yudisial, dan eksaminasi putusan pengadilan. Adapun hasil kerjasama dengan Mahkamah Konstitusi dalam bentuk penelitian dan pelatihan-pelatihan Hukum Acara Mahkamah Konstitusi bagi dosen dan advokat, keikutsertaan mahasiswa dalam proses persidangan. Selain itu, hasil kerjasama FH Usahid dengan Mahkamah
Desember 2021, Volume 7 Nomor 2

Agung dalam bentuk penelitian buku, eksaminasi putusan-putusan pengadilan, yang juga bekerjasama dengan Asosiasi Pimpinan Perguruan Tinggi Hukum Indonesia (APPTHI), serta penelitianpenelitian skripsi mahasiswa $\mathrm{FH}$ Usahid yang terkait dengan putusan pengadilan dalam perkara pidana, perdata, dan PTUN di beberapa Pengadilan Negeri wilayah DKI Jakarta.

Berbagai hasil kerjasama FH Usahid dengan sejumlah institusi di bidang hukum dan penegakannya sebagai mitra, merupakan bagian dari upaya penguatan atas pelaksanaan MBKM, sehingga para mahasiswa fakultas hukum dapat memilih institusi mana yang tepat untuk pemagangan. Hasil kerjasama Fakultas Hukum Usahid dengan berbagai mitra menjadi bagian dari proses penguatan kelembagaan eksternal yang dipersiapkan lebih lanjut untuk pemagangan mahasiswa, sebagai salah satu program MBKM, sehingga mahasiswa Fakultas Hukum Usahid dapat mengembangan dan menyelaraskan antara teori dalam proses perkuliahan dengan praktik hukum di sejumlah lembaga hukum tersebut.

Dalam rangka mendukung MBKM ini Fakultas Hukum Usahid Jakarta telah menjalin kerja sama antar perguruan tinggi hukum. Beberapa diantaranya adalah Fakultas Hukum Universitas Pancabakti 
Morality: Jurnal Ilmu Hukum

Pontianak, Fakultas Hukum Universitas

Warmadewa Bali, Fakultas Hukum dan

Ilmu Sosial Universitas Pendidikan

Nasional Bali, Fakultas Hukum

Universitas Ngurah Rai Bali, dan Fakultas

Hukum Universitas Mahendradatta Bali.

Berbagai kerjasama dengan perguruan tinggi hukum tersebut dalam rangka pelaksanaan pertukaran mahasiswa.

Selanjutnya, juga diefektifkan kerja sama lainnya dengan beberapa kantor hukum, notaris, dan jejaring alumni, organisasi advokat PERADI (Perhimpunan Advokat Indonesia), KAI (Kongres Advokat Indonesia), dan IKADIN (Ikatan Advokat Indonesia).

Tenaga Kependidikan sebagai unsur pendukung civitas akademika dan selama dalam penyelenggaraan di bidang pendidikan, khususnya pada Fakultas Hukum Usahid. Tenaga kependidikan sebagai supporting administration system memberikan kelancaran dalam proses dan tugas-tugas terkait dengan administrasi, misalnya berkaitan dengan rencana akreditasi, rencana kegiatan-kegiatan fakultas dalam pelaksanaan yudisium menjelang wisuda universitas. Selain itu, tenaga kependidikan merupakan elemen penting guna mendukung dan membantu berbagai tugas para dosen dan kepentingan mahasiswa fakultas hukum, serta menjembatani antara mahasiswa dengan
Desember 2021, Volume 7 Nomor 2

dosen dalam hal pembimbingan akademik, memberikan arahan secara teknis administratif untuk pembimbingan skripsi, persyaratan-persyaratan administrasi dan keuangan dalam pelaksanaan ujian, dan hal-hal terkait lainnya.

3. Penguatan internal melalui fasilitas laboratorium hukum sebagai infrastruktur pendukung dalam Pelaksanaan MBKM pada Fakultas Hukum Usahid Jakarta

Dalam mempersiapkan mahasiswa untuk mengikuti pilihan program MBKM, Fakultas Hukum Usahid Jakarta telah mempunyai fasilitas diantaranya:

a. Peradilan semu sebagai tempat praktik persidangan. Praktik beracara sangat penting sebagai pembekalan para mahasiswa fakultas hukum untuk memperkenalkan, mengetahui, dan memahami seluk-beluk peradilan dan institusi penegakan hukum terkait lainnya sebagai suatu sistem. Penggunaan peradilan semu menjadi karakteristik bagi mahasiswa fakultas hukum, khususnya praktik hukum beracara sesuai dengan mata kuliah yang berkarakter hukum acara di pengadilan, baik dalam praktik acara pidana dan acara perdata umum di Pengadilan Negeri, praktik beracara perdata agama di Pengadilan Agama, praktik beracara di Pengadilan Tata 
Usaha Negara, dan praktik beracara di Mahkamah Konstitusi.

b. Lembaga Konsultasi dan Bantuan Hukum (LKBH) yang dapat dimanfaatkan untuk kepentingan pengabdian masyarakat dibidang hukum. Pada lembaga ini mahasiswa dapat melakukan praktik dengan pendampingan dari dosen yang telah mendapatkan izin beracara di pengadilan. Mahasiswa mendampingi dosen dalam melakukan layanan konsultasi hukum dan pendampingan kepada masyarakat atas permasalahan hukum yang dihadapi.

c. Pusat Studi Anti Korupsi dan Pengawasan Pelayanan Publik (PUSTAKO Publik). Lembaga ini dapat menjadi media bagi mahasiswa yang berminat di bidang hukum anti korupsi dan pemerhati pengawasan dan pelayanan publik untuk melakukan kajian hukum dan praktiknya.

d. Pusat Studi Hukum Bisnis. Lembaga ini dapat memfasiliasi mahasiswa bidang peminatan hukum bisnis untuk melakukan pengkajian di bidang hukum bisnis secara lebih mendalam sebagai persiapan untuk memasuki dunia praktik melalui program magang dalam rangka praktik.

Fakultas Hukum Usahid telah melakukan penguatan kelembagaan internal dan eksternal untuk mendukung kesiapan mahasiswa dalam memilih program MBKM. Berbagai fasilitas tersebut telah disiapkan guna memberikan dukungan terhadap pelaksanaan MBKM pada Fakultas Hukum. Mahasiswa Fakultas Hukum Usahid berkapasitas sebagai paralegal dapat mendampingi dosen senior praktisi sejak memberikan jasa konsultasi hukum hingga pendampingan di pengadilan.

Dalam rangka pelaksanaan MBKM, kebebasan belajar para mahasiswa hukum didapatkan dari luar kampus, melalui berbagai permasalahan hukum, sehingga dari permasalahan hukum yang dialami oleh warga masyarakat, mahasiswa mampu memahami dan menganalisis, hingga memberikan solusi atau memecahkan permasalahan hukumnya. Mahasiswa Fakultas Hukum akan secara langsung mendapatkan ilmu dari aspek praktik hukum, dan kemampuan menganalisis permasalahan hukum, dikaitkan dengan teori-teori hukum dan berbagai peraturan perundang-undangan terkait yang didapatkan selama dalam proses perkuliahan.

Berbagai fasilitas yang disiapkan dalam rangka melaksanakan program MBKM tersebut, untuk selanjutnya dapat dikembangkan sendiri oleh para mahasiswa Fakultas Hukum Usahid, 
Morality: Jurnal Ilmu Hukum

sehingga kemampuan softskill di bidang ilmu hukum dapat diasah. Hal ini merupakan esensi dari kebijakan/program MBKM yang ditetapkan oleh Kemenristekdikti. Selain itu, juga terdapat berbagai fasilitas lain guna menunjang program MBKM, salah satunya adalah pelaksanaan magang mahasiswa Fakultas Hukum di beberapa kantor hukum, baik kantor hukum untuk praktik advokat maupun praktik notaris.

Mahasiswa Fakultas Hukum dapat memilih kantor hukum manapun sebagai tempat magang, sehingga kebebasan belajar menjadi faktor terpenting untuk ditekankan dalam proses pembelajaran. Ruang-ruang belajar sangat terbuka, tidak terbatas di ruang kelas, akan tetapi di luar kelas, mahasiswa dapat mengembangkan ilmu hukum sebagai jembatan penghubung antara dunia teoritis dengan praktik hukum di masyarakat. Berbagai institusi negara di bidang hukum dan penegakan hukum tersebut di atas, menjadi penting sebagai pengembangan dan penguatan pelaksanaan MBKM pada Fakultas Hukum Usahid. Mahasiswa akan terbiasa dengan studi kasus beserta pemecahannya atas beberapa perkara, dasar hukum, serta kemampuan analisis dalam perkara yang ada di institusi negara yang berkaitan dengan penegakan hukum, misalnya praktik dalam hukum acara perdata, hukum acara pidana, hukum
Desember 2021, Volume 7 Nomor 2

acara Mahkamah Konstitusi, beserta analisis putusan-putusan pengadilan tersebut.

Pelaksanaan praktik hukum di berbagai institusi hukum (lembaga peradilan, kejaksaan, kepolisian, kantor advokat, dan kantor notaris), sebagai bagian dari program MBKM melalui pemagangan pada berbagai institusi di bidang hukum dan penegakan hukum. Mahasiswa Fakultas Hukum akan didampingi oleh dosen Fakultas Hukum sebagai dosen pembimbing atau fasilitator dalam proses pemagangan berlangsung. Selain praktik hukum dan pemagangan, juga diselenggarakan kuliah umum dan kerjasama antar institusi pemerintahan di bidang hukum. Kuliah umum Fakultas Hukum Usahid Jakarta merupakan kegiatan yang rutin diselenggarakan dalam setiap dua semester sekali, yang dihadiri oleh para mahasiswa Fakultas Hukum semua angkatan dengan mengambil tema yang aktual dan bekerjasama dengan institusi/lembaga negara yang berkaitan dengan hukum dan ketatanegaraan.

\section{KESIMPULAN}

Berdasarkan hasil pembahasan dalam penelitian tersebut, maka dapat disimpulkan bahwa, Fakultas Hukum Usahid telah mempersiapkan terkait pelaksanaan kebijakan/program MBKM 
dengan berbagai peluang yang ada.

Peluang tersebut berkaitan erat dengan kesiapan SDM, baik dosen Fakultas Hukum Usahid yang memiliki latar belakang sebagai praktisi maupun tenaga kependidikan sebagai supporting administration system, akan memudahkan mahasiswa dalam mengambil program MBKM sesuai dengan bidang ilmu yang diminatinya. Selain itu, Fakultas Hukum Usahid sedang dalam proses persiapan dosen pendamping/fasilitator untuk merespon berbagai pilihan mahasiswa atas program MBKM, sementara di sisi lain dihadapkan pada tugas rutin dalam proses pembelajaran. Selain itu, peningkatan kapasitas SDM dalam rangka pelaksanaan MBKM melalui berbagai pelatihan akademik dan aktivitas di luar kampus melalui kegiatan pengembangan penelitian dan pengabdian masyarakat sesuai dengan bidang keilmuan dosen.

Fakultas Hukum Usahid juga telah melakukan penguatan kelembagaan internal dan eksternal untuk mendukung kesiapan mahasiswa dalam memilih program MBKM. Secara internal, berbagai fasilitas telah disiapkan guna memberikan dukungan terhadap pelaksanaan MBKM pada Fakultas Hukum, diantaranya adalah peradilan semu sebagai tempat praktik mahasiswa Fakultas Hukum Usahid beracara, Lembaga Konsultasi dan
Bantuan Hukum (LKBH), PUSTAKO

Publik dan Pusat Studi Hukum Bisnis serta kerja sama dengan kantor hukum. Mahasiswa Fakultas Hukum Usahid berkapasitas sebagai paralegal dapat mendampingi dosen senior praktisi sejak memberikan jasa konsultasi hukum hingga pendampingan di pengadilan. Secara eksternal, beberapa hasil kerjasama Fakultas Hukum Usahid dengan sejumlah institusi/lembaga negara sebagai mitra menjadi bagian dari proses penguatan kelembagaan eksternal untuk pemagangan mahasiswa, yang merupakan salah satu program MBKM, sehingga mahasiswa Fakultas Hukum Usahid dapat mengembangan dan menyelaraskan antara teori dalam proses perkuliahan dengan praktik hukum di sejumlah lembaga hukum tersebut.

Dalam penemuan pada penelitian ini, terkait dampak kebijakan MBKM dalam mempersiapkan pelaksanaannya pada Fakultas Hukum Usahid ini, Penulis memberikan saran pertama, Kemenristekdikti, perlu lebih masif lagi untuk melakukan sosialisasi program MBKM, bukan hanya kepada kalangan Perguruan Tinggi, akan tetapi juga kepada lembaga lain, baik pemerintah maupun swasta untuk memberikan pemahaman yang sama dan dukungan semua elemen bangsa dalam mendukung pelaksanaan 
Morality: Jurnal Ilmu Hukum

program MBKM dan kedua,

Kemenristekdikti membuat kebijakan yang meniadakan keharusan keberadaan perjanjian kerja sama secara fisik antara Perguruan Tinggi dengan calon Mitra program MBKM untuk memudahkan mahasiswa menetapkan pilihannya.

Terakhir, penelitian ini dapat dilakukan oleh dukungan seluruh pihak, karena itu Kami Tim Peneliti Fakultas Hukum Universitas Sahid Jakarta mengucapkan banyak terima kasih kepada Kemenristekdikti yang telah memberikan dukungan dana selama dalam proses penelitian terkait dengan dampak kebijakan MBKM pada Fakultas Hukum Usahid Jakarta. Selain itu, juga dukungan kepada LPPM Usahid atas kelancaran dalam pelaksanaan penelitian ini, dan luaran publikasi ilmiah dalam bentuk jurnal, serta pihak Tim Editorial MORALITY: Jurnal Ilmu Hukum pada Fakultas Hukum Universitas PGRI Palangka Raya Kalimantan Tengah, dalam mempertimbangkan untuk dimuatnya artikel hasil penelitian ini.

\section{DAFTAR RUJUKAN}

Buku Panduan Merdeka Belajar - Kampus Merdeka Direktorat Jenderal Pendidikan Tinggi, Direktorat Jenderal Pendidikan Tinggi Kemdikbud RI, Tahun 2020.
Buku Panduan Merdeka Belajar-Kampus Merdeka Universitas Sahid Jakarta, Tahun 2021.

Harian Kompas (2020). https://edukasi.kompas.com/read/202 0/01/25/11354331/ini-rangkuman-4kebijakan-kampus-merdekamendikbud-nadiem?page $=$ all, diakses pada tanggal 26 Desember 2021

Kegiatan Focus Group Discussion (FGD) bertema: "Dampak Kebijakan MBKM pada Fakultas Hukum Usahid", dengan peserta para dosen di lingkungan Fakultas Hukum Usahid di Hotel Bidakara pada tanggal 17 Desember 2021, Pukul 09.00 WIB.

Kegiatan Sosialisasi MBKM (Merdeka Belajar-Kampus Merdeka) kepada para mahasiswa Fakultas Hukum Usahid yang diselenggarakan oleh Fakultas Hukum Universitas Sahid Jakarta melalui daring (zoom) pada hari Rabu, 15 Desember 2021, Pukul $12.30 \mathrm{WIB}$.

Keputusan Menteri Pendidikan dan Kebudayaan NOMOR 754/ P/2020 tentang Indikator Kinerja Utama Perguruan Tinggi Negeri dan Lembaga Layanan Pendidikan Tinggi di Lingkungan Kementerian Pendidikan dan Kebudayaan Tahun 2020

Keputusan Rektor Universitas Sahid Jakarta Nomor 130/USJ-01/A50/2020 tentang Panduan Akademik Merdeka Belajar-Kampus Merdeka Universitas Sahid Jakarta

Marzali, A. (2012). Antropologi dan Kebijakan Publik. KENCANA PRENADA MEDIA GROUP. 
Miswardi, dkk. (2021). Etika, Moralitas dan Penegak Hukum Peraturan Perundang-undangan, Januari, Jurnal Menara Ilmu LPPM UMSB, 15 (02), 150-162.

https://jurnal.umsb.ac.id/index.php/m enarailmu/article/download/2425/189 6

Nofia, N.N. (2020). Analisis Tantangan Implementasi Kebijakan "Merdeka Belajar Kampus Merdeka" pada Perguruan Tinggi Islam Negeri di Indonesia, PRODU: Prokurasi Edukasi-Jurnal Manajemen Pendidikan Islam, 1 (2), 61-72. https://ejournal.uinib.ac.id/jurnal/inde x.php/produ/article/view/3328, https://doi.org/10.15548/pprokurasi.v1i2.3328

Panduan Penyusunan Kurikulum Pendidikan Tinggi, Di Era Industri 4.0 Untuk Mendukung Merdeka Belajar-Kampus Merdeka yang disusun oleh Dirjen Dikti Kemenristekdikti Tahun 2020.

Peraturan Pemerintah Nomor 04 Tahun 2014 tentang Penyelenggaraan Pendidikan Tinggi dan Pengelolaan Perguruan Tinggi

Peraturan Presiden Nomor 8 Tahun 2012, tentang Kerangka Kualifikasi Nasional Indonesia (KKNI)

Peraturan Menteri Pendidikan dan Kebudayaan No. 3 Tahun 2020 tentang Standar Nasional Pendidikan Tinggi

Sinaga, N.A. (2020). Kode Etik Sebagai Pedoman Pelaksanaan Profesi Hukum yang Baik, Jurnal Ilmiah Hukum Dirgantara, Fakultas Hukum Universitas Dirgantara Marsekal Suryadarma, 10 (2), 1-34. https://journal.universitassuryadar ma.ac.id/index.php/jihd/article/vie $\mathrm{w} / 460$

Siregar, N., dkk. (2020). Konsep Kampus Merdeka Belajar di Era Revolusi Industri 4.0, Fitrah: Journal of Islamic Education (FJIE) 1 (1), 140-157. http://jurnal.staisumateramedan.ac.id/index.php/fitrah/article /view/13, https://doi.org/10.53802/fitrah.v1i1 .13

Sudaryanto, dkk. (2020). Konsep Merdeka Belajar-Kampus Merdeka dan Aplikasinya dalam Pendidikan Bahasa (dan Sastra) Indonesia, Kode: Jurnal Bahasa, Universitas Negeri medan (Unimed), 9 (2), 7893.

https://jurnal.unimed.ac.id/2012/in dex.php/kjb/article/view/18379 https://doi.org/10.24114/kjb.v9i2.1 8379

Susilawati, N. (2021). Merdeka Belajar dan Kampus Merdeka Dalam Pandangan Filsafat Pendidikan Humanisme, Jurnal Sikola: Jurnal Kajian Pendidikan dan Pembelajaran, Universitas Negeri Padang, 2 (3), 203-219. http://sikola.ppj.unp.ac.id/index.ph p/sikola/article/view/108/55,https:// doi.org/10.24036/sikola.v2i3.108

Tahir, A. (2011). Kebijakan Publik dan Transparansi Penyelenggaraan Pemerintahan Daerah, PUSTAKA INDONESIA PRESS.

Undang-Undang Nomor 12 Tahun 2012 tentang Pendidikan Tinggi

Undang-Undang Nomor 20 Tahun 2003 tentang Sistem Pendidikan Nasional

Peraturan Pemerintah Nomor 04 Tahun 2014 tentang Penyelenggaraan Pendidikan Tinggi dan Pengelolaan Perguruan Tinggi 
Yuberti, Teori Pembelajaran dan

Pengembangan Bahan Ajar Dalam

Pendidikan, Anugrah Utama Raharja

(AURA), 2014. 